\title{
Penggunaan Limbah Industri Jamu dan Bakteri Asam Laktat (Lactobacillus sp.) sebagai Sinbiotik untuk Aditif Pakan Terhadap Kualitas Interior Telur Ayam Ras Petelur
}

\section{Utilization of Herbal Industry Waste and Lactic Acid Bacteria (Lactobacillus sp.) as Synbiotic for Interior Quality of Laying Hen Eggs}

\author{
Y. Wijaya*, E. Suprijatna dan S. Kismiati \\ Fakultas Peternakan dan Pertanian, Universitas Diponegoro, Semarang, 50275 \\ *E-mail: wijayayudis5@gmail.com
}

(Diterima: 15 Februari 2017; Disetujui: 11 April 2017)

\begin{abstract}
ABSTRAK
Penelitian ini bertujuan untuk mengetahui pengaruh penambahan sinbiotik sebagai aditif pakan ayam petelur terhadap kualitas interior telur. Penelitian ini menggunakan materi ayam ras petelur sebanyak 100 ekor dengan umur 40 minggu. Ayam ras petelur memiliki bobot badan 1,81 $\pm 0,12$ gram. Perlakuan digunakan yaitu penambahan sinbiotik dengan level $0,5 \%, 1,0 \%$, dan 1,5\%. Penelitian ini menggunakan ransum yang terdiri dari bungkil kedelai, jagung, bekatul, meat bone meal, premix dan pakan tambahan. Penelitian ini menggunakan rancangan acak lengkap yang terdiri dari 4 perlakuan 5 ulangan. Menggunakan 20 unit percobaan yang terdiri dari 5 ekor ayam ras petelur. Data yang diperoleh dianalisis menggunakan analisis ragam dan uji duncan pada taraf 5\%. Hasil menunjukkan bahwa penambahan sinbiotik tidak berpengaruh nyata terhadap Indeks putih telur, Indeks kuning telur dan haugh unit $(\mathrm{P}>0,05)$, sedangkan untuk warna kuning telur berpengaruh nyata $(\mathrm{P}<0,05)$. Kesimpulan penelitian ini penambahan sinbiotik pada level 1,0-1,5\% meningkatkan warna kuning telur.
\end{abstract}

Kata kunci: limbah jamu, bakteri asam laktat, sinbiotik, kualitas interior telur

\section{ABSTRACT}

This study was to determine the effect of synbiotic as a feed additive of laying hens for the interior egg quality. This study used 100 laying hens which are 40 weeks old as the material. The body weight of laying hens are $1.81 \pm 0.12$ grams. The treatment used in this study was the addition of synbiotic to the level of $0.5 \%, 1.0 \%$ and $1.5 \%$. This study uses a ration that consist of soybean meal, corn, rice bran, meat bone meal, premix and feed supplement. The research method was experiment laboratory using a completely randomized design with 4 treatments consisting of 5 replicates. Using 20 experimental units consisting 5 laying hens. The data was analyzed by using analysis of variance and F test at 5\% level. The results showed that the addition of synbiotic did gave significant effect on egg white index, egg yolk index and Haugh units $(P>0.05)$, while for the color of egg yolk affacted significantly $(P<0.05)$. The conclusion of this study was addition of synbiotic at the level of 1.0-1.5\% increase egg yolk color.

Keywords: waste herbs, lactic acid bacteria, symbiotic, interior egg quality

\section{PENDAHULUAN}

Usaha peternakan khususnya ayam petelur semakin banyak diminati oleh para peternak karena konsumsi telur dari masyarakat Indonesia semakin meningkat, namun dalam pengembangan usaha peternakan ayam petelur tersebut terhambat karena faktor iklim di Indonesia yaitu iklim tropis (Sarwono, 2000). Faktor temperatur lingkungan dan kelembaban yang tinggi dapat meningkatkan tingkat stress ayam sehingga konsumsi pakan menurun dan menyebabkan menurunnya pula tingkat produktivitas (Argo et al., 2013)

Berbagai upaya untuk meningkatkan efisiensi penggunanan pakan ayam didaerah tropis telah banyak dilakukan, salah satunya 
adalah penggunaan tambahan antibiotik dalam ransum, tetapi penggunaan antibiotik yang berlebihan dapat menyebabkan residu terhadap produk yang dihasilkan ternak dan tumbuhnya bakteri kebal antibiotik (Willard et al., 2000). Dewasa ini banyak dikembangkan zat-zat untuk memperbaiki kualitas telur yang berasal dari bahan organik, seperti probiotik dan prebiotik, tetapi penggunaan keduanya secara bersamaan menjadi sinbiotik masih jarang dilakukan (Muharlien, 2010).

Sinbiotik merupakan gabungan antara probiotik dan prebiotik yang berfungsi untuk mengoptimalkan fungsi saluran pencernaan dengan cara menyeimbangkan mikroflora yang ada pada saluran pencernaan. Prebiotik berfungsi menyediakan substrat untuk probiotik, sehingga probiotik dapat berkembang secara optimal. Serat kasar yang tidak dapat dicerna dalam usus halus akan difermentasi probiotik menjadi asamasam rantai pendek mudah terbang, yang menyebabkan $\mathrm{pH}$ menjadi rendah (5-4). Keadaan asam pada saluran pencernaan akan menghambat pertumbuhan bakteri patogen dan meningkatkan fungsi enzim protease (Gabriela, 2010). Penggunaan sinbiotik sebagai aditif pakan mampu mengefisiensikan penggunaan pakan, meningkatkan produktivitas dan kesehatan ayam, sehingga kualitas interior telur dapat meningkat (Youssev et al., 2013)

Probiotik merupakan kelompok bakteri atau mikrobia menguntungkan yang bekerja dengan menghasilkan asam asam organik untuk menyeimbangkan mikrofloral yang ada dalam saluran pencernaan. Mikrobia yang biasa digunakan sebagai probiotik antara lain, strecoccus, lactobacillus sp, enterococcus, bacillus sp. Dosis penggunaan probiotik yang berpengaruh nyata sebesar $10^{6}-10^{9} \mathrm{CFU} /$ Kg. Kinerja probiotik yaitu menstabilkan mikroflora pencernaan (Gallazzi et al., 2016). Karakteristik probiotik yang baik antara lain, mempunyai identifikasi taksonomi yang jelas, dapat bertahan, berkolonisasi dan bermetabolisme secara aktif, tahan terhadap cairan pencernaan dan empedu, persisten dalam saluran pencernaan, menempel pada epitelium atau mucus, berkompetisi dengan mikroflora inang (Gaggia et al., 2010).

Prebiotik merupakan substrat atau nutrisi untuk prebiotik agar dapat menjalankan kinerjanya dengan baik serta sebagai pakan tambahan untuk meningkatkan keseimbangan mikroba di saluran pencernaan. Prebiotik dapat menjadi sumber energi dan atau nutrien terbatas lainnya bagi mukosa usus dan substrat untuk fermentasi bakteri cecal dalam menghasilkan vitamin dan antioksidan yang dapat menguntungkan (Mountzouris et al., 2010). Prebiotik yang digunakan biasanya mengandung oligosakarida. Oligosakarida merupakan komponen utama prebiotik. Jenis oligosakarida bervariasi seperti, fruktosa, galaktosa, ribosa, arabinosa, manosa (Durst, 1996). Menurut penelitian sebelumnya hanya menggunakan probiotik saja sehingga kurang optimal dalam menjalankan fungsinya pada saluran pencernaan, selain itu perbedaan hasil disebakan karena faktor genetik seperti, perbedaan starain dan umur ayam; keadaan lingkungan serta bahan dari probiotik yang digunakanLimbah jamu dapat digunakan sebagai prebotik karena terdapat kandungan oligosakarida. Oligosakarida dapat dimanfaatkan oleh bakteri yang ada didalam probiotik tersebut (Haryati, 2011). Oligosakarida meiliki berbagai jenis yaitu arabinosa, manosa dan sukrosa (Balai Penelitian Ternak Ciawi, 2016). Limbah jamu sendiri menggunakan limbah dengan bentuk padat, juga mengandung zat aktif seperti, alkoloid, fenolik, tripenoid, minyak atsiri glikosida yang dapat meningkatkan performan ayam petelur, sehingga kualitas interior telur juga meningkat (Zainudin, 2006). Minyak atsiri yang terkandung dalam limbah jamu dapat meningkatkan nafsu makan ternak, sehingga kebutuhan nutrisi ternak dapat tercukupi (Kurtini et al., 2014). Kebutuhan nutrisi seperti protein yang tercukupi akan meningkatkan produktivitas ternak, sehingga kualitas interior telur juga akan meningkat.

Penelitian ini bertujuan untuk mengevaluasi kualitas interior telur dilihat 
dari Indeks putih telur, Indeks kuning telur, warna kuning telur dan haugh unit. Penelitian ini memiliki manfaat yaitu dapat mengetahui dosis sinbiotik yang optimal yang dapat meningkatkan kualitas interior ayam ras petelur.

\section{METODE}

Penelitian ini menggunakan materi ayam ras petelur sebanyak 100 ekor dengan umur 40 minggu. Ayam ras petelur memiliki bobot badan $1.81 \pm 0,12$ gram. Penelitian ini menggunakan ransum yang terdiri dari bungkil kedelai, jagung, bekatul, meat bone meal, premix dan pakan tambahan. Pembuatan sinbiotik dilakukan dengan mencampur $150 \mathrm{ml}$ larutan kultur murni bakteri asam laktat jenis lactobacillius sp. dengan $1 \mathrm{~kg}$ ampas jamu. Kandungan bakteri asam laktat menghasilkan $60 \times 10^{7} \mathrm{CFU} / \mathrm{Kg}$. Pengamatan parameter kualitas interior telur dilakukan 1 kali setiap minggu, selama 8 kali pengambilan data. Pengambilan sampel sebanyak 2 telur per unit percobaan. Penelitian ini menggunakan rancangan acak lengkap terdiri dari 4 perlakuan 5 ulangan. Menggunakan 20 unit percobaan yang terdiri dari 5 ekor ayam ras petelur.

Perlakuan yang digunakan ada 4 yaitu :

T0: Pemberian pakan tanpa penambahan sinbiotik

T1: Pemberian pakan dengan penambahan sinbiotik $0,5 \%$

T2: Pemberian pakan dengan penambahan sinbiotik $1,0 \%$

T3: Pemberian pakan dengan penambahan sinbiotik $1,5 \%$

Parameter yang diukur :

1. Indeks putih telur : $\frac{H}{0,5(D 1+D Z}$

Indeks putih telur diukur dengan menggunakan micrometer dan tripodmecrometer. Fungsi mikrometer yaitu mengukur panjang dan lebar telur

Tabel 1. Kandungan Ransum Pakan Penelitian.

\begin{tabular}{lrrrr}
\hline Komposisi Bahan Pakan & $\mathrm{T} 0$ & $\mathrm{~T} 1$ & $\mathrm{~T} 2$ & $\mathrm{~T} 3$ \\
\hline Jagung (\%) & 53,80 & 53,80 & 53,80 & 53,80 \\
Bungkil Kedelai (\%) & 18,93 & 18,93 & 18,93 & 18,93 \\
Bekatul(\%) & 11,86 & 11,86 & 11,86 & 11,86 \\
Meat Bone Meal (\%) & 5,99 & 5,99 & 5,99 & 5,99 \\
Grit (\%) & 8,40 & 8,40 & 8,40 & 8,40 \\
Premix (\%) & 1,00 & 1,00 & 1,00 & 1,00 \\
Jumlah & 100 & 100 & 100 & 100 \\
Sinbiotik & 0,00 & 0,50 & 1,00 & 1,50 \\
\hline Jumlah Setelah Penambahan Sinbiotik & 100 & 100,50 & 101,00 & 101,50 \\
\hline Kandungan nutrisi dalam ransum & & & & \\
Lemak Kasar (\%) & 2,641 & 2,62 & 2,61 & 2,6 \\
Serat Kasar (\%) $^{2}$ & 4,69 & 4,66 & 4,64 & 4,62 \\
Protein Kasar (\%) & 17,44 & 17,35 & 17,26 & 17,18 \\
Kadar Abu (\%) $^{2}$ & 13,73 & 13,66 & 13,59 & 13,52 \\
Kadar Air (\%) $^{2}$ & 10,62 & 10,56 & 10,51 & 10,46 \\
Energi Metabolisme (kkal/kg) $^{3}$ & 3213,19 & 3197,20 & 3181,37 & 316570,44 \\
\hline Ketran
\end{tabular}

Keterangan:

${ }^{1}$ Hasil Analisis Laboratorium Ilmu Nutrisi Pakan FPP Undip (2017)

${ }^{2}$ Hasil Analisis Laboratorium Sidomuncul Pupuk Nusantara Bawen Semarang (2016)

${ }^{3} \mathrm{EM}$ dihitung menggunakan rumus balton :

$\mathrm{EM}(\mathrm{kkal} / \mathrm{kg})=40.81[0.87(\mathrm{PK}+2.25 \mathrm{x} \mathrm{LK}+\mathrm{BETN})+\mathrm{K}]($ Indreswaei et al., 2009). 
Tabel 2. Rataan Indeks putih telur, Indek kuning telur, warna kuning telur dan haugh unit.

\begin{tabular}{lcccc}
\hline \multirow{2}{*}{ Parameter } & \multicolumn{4}{c}{ Perlakuan } \\
\cline { 2 - 5 } & $\mathrm{T} 0$ & $\mathrm{~T} 1$ & $\mathrm{~T} 2$ & $\mathrm{~T} 3$ \\
\hline Indeks putih telur & $0.139 \pm 0.014$ & $0.133 \pm 0.011$ & $0.136 \pm 0.010$ & $0.135 \pm 0.024$ \\
Indeks kuning telur & $0.475 \pm 0.005$ & $0.467 \pm 0.017$ & $0.476 \pm 0.015$ & $0.475 \pm 0.015$ \\
Warna kuning telur & $8.825 \pm 0.58^{\mathrm{c}}$ & $9.450 \pm 0.50^{\mathrm{b}}$ & $10.225 \pm 0.22^{\mathrm{a}}$ & $9.275 \pm 0.24^{\mathrm{bc}}$ \\
Haugh unit & $95.934 \pm 4.24$ & $94.302 \pm 2.85$ & $96.572 \pm 230$ & $96.602 \pm 4337$ \\
\hline
\end{tabular}

Keterangan: Huruf yang berbeda pada baris yang sama menunjukkan perbedaan yang nyata $(\mathrm{P}<0.05)$.

dan tripodmicrometer untuk mengukur ketinggian putih telur.

2. Indeks kuning telur: $\frac{n}{0,5(a 1+d 2)}$

Indeks kuning telur diukur dengan menggunakan micrometer dan tripodmicrometer. Fungsi micrometer yaitu mengukur panjang dan lebar telur dan tripodmicrometer untuk mengukur ketinggian kuning telur.

3. Haugh unit:

$\mathrm{HU}: 100 \log \left(\mathrm{H}+7,57-1,7^{0,37}\right)$

4. Warna kuning telur:

Alat yang digunakan untuk mengukur warna kuning telur dengan yolk color fan terdapat penilaian dari 1-12.

Ket: H: Tinggi putih telur

$\mathrm{H}$ : Tinggi kuning telur

W: Berat telur

$\mathrm{D}_{1}$ dan $\mathrm{D}_{2}$ : Diameterputih telur

$\mathrm{d}_{1}$ dan $\mathrm{d}_{2}$ : diameter kuning telur

Data diolah menggunakan analisis ragam, jika ada pengaruh perlakun dilakukan ke uji Duncan.

\section{HASIL DAN PEMBAHASAN}

Data hasil pengamatan pengaruh penambahan sinbiotik terhadap kualitas interior telur.

\section{Indeks Putih Telur}

Berdasarkan Tabel 2. diperoleh rata rata indeks putih telur adalah $0,136 \pm 0,015$. Nilai indeks putih telur tersebut termasuk dalam kisaran standar. Hal ini sesuai pendapat Argo et al. (2013), nilai standar indek putih telur yaitu $0,135-0,139$.

Berdasarkan uji statistik, pemberian sinbiotik tidak berpengaruh nyata $(\mathrm{P}>0,05)$ terhadap indeks putih telur. Hal ini diduga salah satunya karena konsumsi protein pada penelitian ini tidak berbeda nyata, sehingga indeks putih telur juga tidak berbeda nyata dengan perlakuan kontrol(T0). Hasil penelitian ini sejalan dengan penelitian Gabriela et al. (2010), penambahan sinbiotik pada taraf $1 \%$ dengan komposisi (Enterococcus faecium + ganggang laut) yang diberikan pada ayam petelur umur 57 minggu tidak berpengaruh nyata terhadap indeks putih telur (Yuwanta, 2002).

Penggunaan sinbiotik dalam penelitian ini belum mampu meningkatkan indeks putih telur. Peran prebiotik (limbah jamu) hanya menyediakan substrat untuk probiotik (Zainudin, 2006). Probiotik dalam saluran pencernaan berperan membantu metabolisme zat-zat nutrien. Konsumsi dan kecernaan protein dalam penelitian ini yang tidak berbeda nyata menyebabkan kualitas interior telur (indeks putih telur) juga tidak berbeda nyata terhadap perlakuan kontrol (Winarno dan Koswana, 2002).

Bahan utama untuk menentukan tinggi putih telur dan pembentukan ovumucin itu terletak pada konsumsi protein. Hal ini sesuai dengan pendapat Yuwanta (2002), semakin tinggi konsumsi protein, maka pembentukan ovumucin juga semakin besar, sehingga semakin tinggi indeks putih telur. Hartono dan Tintin (2015) menambahkan, indeks putih telur dipengaruhi oleh protein pakan, pemberian pakan dan formulasi ransum harus memenuhi kebutuhan ternak agar mampu 
meningkatkan kualitas interior telur seperti indeks putih telur.

Menurut penelitian Owings et al. (1990) penambahan sinbiotik untuk meningkatkan kualitas indeks putih telur bukan faktor tunggal, tetapi banyak faktor juga mempengaruhi kinerjanya yaitu komposisi mikroba inang, cara pemberian probiotik dan jenis probiotiknya. Indeks putih telur ditentukan oleh tinggi putih telur kental, faktor yang mempengaruhi kekentalan putih telur antara lain, genetik ternak seperti umur, strain ;fisiologi ternak, fisiologi lingkungan ternak; kemampuan saluran pencernaan ternak dalam menyerap zat-zat nutrien, kebutuhan nutrisi ransum ternak, terutama kebutuhan protein untuk ternak unggas (Joseph et al., 2006).

\section{Indeks Kuning Telur}

Berdasarkan Tabel 2. diperoleh rata rata indeks kuning telur sebesar $0,47 \pm 0,01$. Nilai indeks kuning telur yang diperoleh dari hasil penelitian tergolong normal. Hal ini sesuai pendapat Agro et al. (2013), standar normal nilai indeks kuning telur yaitu berkisar 0,30 0,50 .

Berdasarkan analisis statistik, pemberian sinbiotik tidak berpengaruh nyata $(\mathrm{P}>0,05)$ terhadap indeks kuning telur. Hal ini salah satunya diduga karena kualitas nutrisi dan kemampuan ternak dalam menyerap zat-zat nutrien. Penelitian ini sejalan dengan penelitian Youssef et al. (2013), penambahan sinbiotik pada taraf $0,06 \%$ yang diberikan pada ayam petelur umur 27 minggu tidak berpengaruh terhadap indeks kuning telur.

Dalam penelitian yang sudah dilakukan ini penggunaan sinbiotik belum mampu meningkatkan kecernaan serat kasar, sehingga penyerapan zat-zat nutrien, seperti protein, lemak juga tidak meningkat (Yesilbag, 2006). Peran probiotik yang mendapat substrat dari prebiotik belum mampu meningkatkan zat-zat nutrien seperti protein, yang diduga karena probiotik yang digunakan berasal dari bakteri tunggal sehingga perannya untuk dapat meningkatkan kinerja kecernaan nutrient yang belum baik. Hal ini sesuai dengan pendapat Pribadi et al. (2015), penambahan sinbiotik yang berasal dari gabungan antara bakteri inokulum Saccharomyces cerevisiae, inokulum Rhizophus sp. dan inokulum Bacillus sp. dapat meningkatkan kualitas interior telur seperti indeks kuning telur.

Nilai indeks kuning telur dipengaruhi oleh kandungan protein, lemak dan mineral. Kecernaan protein dan serat kasar yang tidak berbeda mengakibatkan nilai indeks kuning telur juga tidak berbeda (Rahman, 2008). Kandungan protein dapat merangsang pembentukan membran vitelin. Indeks kuning telur dapat dipengaruhi oleh kandungan protein yang dapat merangsang terbentuknya membrane vitelin. Semakin tipis membran vitelin, karena berpindahnya air dari dalam putih ke kuning telur ini mengakibatkan kuning telur menjadi encer dan nilai indeks kuning telur menjadi rendah (Kurtini et al., 2014).

Nilai kuning telur dipengaruhi oleh kandungan lemak yang ada dikuning telur. Hal ini sesuai dengan pendapat Bell dan Weaver, (2002), kandungan lemak di dalam kuning telur dapat dipengaruhi oleh kandungan lemak pakan (Yamamoto et al., 2007), Asam lemak yang banyak terdapat pada kuning telur adalah linoleat, oleat dan stearat. Kuning telur miliki nilai kandungan protein $16 \%$, glukosa $2 \%$, lemak $35 \%$ dan air $50 \%$. Kuning telur yang menggelembung dan kokoh ditentukan oleh keadaan membrane vitelin, selain itu protein pakan dapat mempangaruhi khalaza yang ada dikuning telur (Kurtini et al., 2014). Kesegaran telur juga mempengaruhi indeks kuning telur. Telur segar memiliki variasi nilai indeks kuning telur yang relatif kecil (Robert, 2004).

\section{Warna Kuning Telur}

Berdasarkan Tabel 2. diperoleh rata rata warna kuning telur sebesar 9,44 $\pm 0,39$. Nilai warna kuning telur tergolong normal. Standar nilai warna kuning telur yang baik berada pada kisaran 7-12 (Stadellman, 1995). Berdasarkan analisis statistik, pemberian sinbiotik 
berpengaruh nyata $(\mathrm{P}<0,05)$ terhadap warna kuning telur. Peningkatan warna kuning telur terjadi pada perlakuan T1-T2 dengan taraf pemberian $(0,5-1,0 \%)$, sedangkan pada penambahan sinbiotik dengan taraf yang lebih tinggi $(1,5 \%)$ akan menurunkan warna kuning telur, tetapi penurunan warna kuning telur pada perlakuan T3 tidak berbeda nyata dengan perlakuan kontrol (T0).

Penelitian ini sejalan dengan penelitian terdahulu, tetapi hasil dari penelitian ini lebih tinggi. Menurut penelitian Youseef et al. (2010) penambahan sinbiotik pada taraf $0,06 \%$ yang diberikan pada ayam petelur umur 27 minggu berpengaruh terhadap warna kuning telur memiliki rata - rata berkisar 7,80. Perbedaan nilai warna kuning telur diduga karena pada penelitian Hausman dan Sandman (2000), dosis penggunaan sinbiotik terlalu rendah, sehingga peran bakteri baik untuk menyeimbangkan bakteri dalam saluran pencernaan kecil.

Pemberian sinbiotik ini dapat meningkatkan warna kuning telur karena kandungan $\beta$ karoten dalam ransum yang dapat diserap dengan baik setelah penambahan sinbiotik. $\beta$ karoten banyak terdapat pada bahan pakan asal seperti tanaman dengan serat kasar tinggi (jagung, bungkil kedelai dan bekatul) Menurut (Youseef et al., 2010). Penambahan sinbiotik dapat meningkatkan metabolism zat - zat nutrient menjadi asam lemak rantai pendek, sehingga mudah diserap tubuh. Pada perlakuan kontrol (tanpa penambahan sinbiotik) kandungan serat kasar ransum masih tinggi, sehingga menghalangi penyerapan nutrient dan $\beta$ karoten masih terikat. Pada perlakuan penambahan sinbiotik yang dapat meningkatkan metabolisme nutrien yang menyebabkan $\beta$ karoten dapat diserap dengan baik, sehingga dapat meningkatkan warna kuning telur. Hal ini sesuai dengan pendapat Hausman dan Sandman (2000), pembentukan warna kuning telur dipengaruhi oleh kandungan $\beta$ karoten, semakin banyak $\beta$ karoten yang diserap oleh tubuh ternak maka nilai warna kuning telur semakin meningkat.

Faktor yang mempengaruhi warna kuning telur yaitu zat- zat yang ada didalam pakan yaitu antara lain beta karoten, klorofil, xantofil dan cytosan (Sahara, 2010). Pigmen pemberian warna kuning telur yang ada didalam pakan akan diserap oleh organ yang ada didalam saluran pencernaan Zainudin (2006).

\section{Pengaruh Penambahan Sinbiotik terhadap Haugh Unit}

Berdasarkan Tabel 2. diperoleh rata rata Haugh unit sebesar 94,74 $\pm 3,43$. Nilai haugh unit sesuai standar normal. Hal ini sesuai pendapat Jones (2006), Haugh unit mengelompokan berdasarkan kualitas telur kualitas AA apabila nilai haugh unit diatas 79, kualitas A apabila nilai haugh unit berkisar antara 55-78, kualitas B apabila nilai haugh unit berkisar antara 31-54 dan kualitas C apabila nilai haugh unit kurang dari 31 . Berdasarkan hasil penelitian ini, nilai Haugh unit termasuk dalam katagori kualitas AA yaitu diatas nilai 79 .

Berdasarkan uji statistik, pemberian sinbiotik tidak berpengaruh nyata $(\mathrm{P}>0,05)$. Hasil penelitian ini benar dilakukan oleh penelitian Gabriela et al. (2010), penambahan sinbiotik pada taraf $1 \%$ dengan komposisi (Enterococcus faecium + ganggang laut) yang diberikan pada ayam petelur umur 57 minggu tidak berpengaruh nyata terhadap haugh unit. Berbeda dengan penelitian Nugraha et al. (2013), penambahan gabungan antara bakteri Lactobacillus sp. dan bacillus sp. yang diberikan pada ayam arab umur 90 minggu berpengaruh nyata terhadap nilai haugh unit. Perbedaan ini diduga disebabkan karena strain ayam yang digunakan dan jumlah bakteri yang digunakan.

Penggunaan sinbiotik pada penelitian ini belum mampu meningkatkan nilai Haugh unit. Hal ini diduga karena peran probiotik yang telah mendapat substrat dari prebiotik belum mampu meningkatkan penyerapan nutrien. Kecernaan serat kasar pada penelitian ini yang tidak berbeda nyata menyebabkan kecernaan nutrien, seperti protein juga tidak berbeda nyata dengan perlakuan kontrol. 
Nilai haugh unit berbanding lurus dengan nilai indeks putih telur (Stadelman dan Cotteril, 1995). Nilai indeks putih telur yang tidak berbeda nyata menyebabkan nilai haugh unit juga tidak berbeda. Penyerapan nutrisi yang optimal, terutama penyerapan protein, sehingga dapat meningkatkan kekentalan putih telur Haugh Unit (Nugraha et al., 2013).

Menurut Muchtadi dan Sugiono (1992) Penurunan nilai Haugh Unit terjadi karena penguapan air dalam telur dan kantung udara yang bertambah besar. Faktor yang memepngaruhi nilai haugh unit yaitu kualitas nutrisi, umur ternak, dan aspek lingkungan. Umur ayam yang semakin tua dan suhu lingkungan yang tinggi akan menurunkan nilai haugh unit (Syamsir, 1994). Nilai Haugh Unit dibawah standar mengakibatkan kondisi albumin menjadi menggembung, karena kondisi lingkungan sekitar yaitu suhu yang tinggi dan kelembaban remdah (Jones, 2006).

\section{KESIMPULAN}

Penambahan sinbiotik terhadap kualitas interior telur bisa digunakan pada taraf taraf $1-1,5 \%$ meningkatkan warna kuning telur, tetapi tidak berpengaruh terhadap indeks putih telur, indeks kuning telur dan haugh unit.

\section{DAFTAR PUSTAKA}

Argo, L. B., Tristiarti dan I. Mangisah. 2013. Kualitas Fisik Telur Ayam Arab Petelur Fase 1 dengan Berbagai Level Azolla Microphilla. Journal of Animal Agriculture. 2 (1): 9-10.

Balai Penelitian Ternak. 2016. Ciawi, Bogor.

Bell, D. dan Weaver. 2002. Commercial chicken meat and egg. Kluwer Academic Publishers, United J. IlmuIlmu Peternakan 23 (2):19 - 2424 States of America.

Durst, L. 1996. Inclusion of fructooligosaccharides in broiler diets.
Archiv. Geflugelkunde 60: 160 - 164.

Gabriela, C. R. 2010. Effect of a synbiotic feed additiveSupplementation on laying hens performance and eggs quality. J. Veterinary. Vol 53: 89-93.

Gaggia, F., P. Mattarelli and B. Biavati. 2010. Probiotic and prebiotics in animal feeding for safe food production. Intl. J. Food Microbiol. 14: 515 - 528.

Gallazzi, D., A. Giardini, G. M. Mangiagalli, S. Marelli, V. Ferrazzi, C. Orsi dan G. L. Cavalchini. 2016. Effects of Lactobacillus acidophilus D2/CSL on laying hen performance. Ital. J. Anim. Sci. Vol. 7 : 27-37

Hartono, M. dan T. Kurtini. 2015 Pengaruh pemberian probiotik terhadap performa ayam petelur. J Penelitian Pertanian Terapan 15 (3): 214-219.

Haryati, T. 2011. Probiotik dan prebiotik sebagai pakan imbuhan ternak nonruminansia. J. Wartazoa. 3(21) : 125-132

Hausmann, A. dan G. Sandmann. 2000. A single fi ve-step desaturase is involved in the carotenoid biosynthesis pathway to beta-carotene and torulene in Neurospora crassa. J. Genet. Biol. 30: 147-53.

Jones, D. R. 2006. Conserving and Monitoring Shell Egg Quality. Proceedings of the 18th Annual Australian Poultry Science Symposium. p. 157-165.

Joseph, N. S., F. E. Robinson, D. R. Korver and R. A. Renema. 2000. Effect of dietary protein intake during the pulletto-breeder transition period on early egg weight and production in broiler breeders. Poult. Sci. 79: 1790-1796

Kurtini, T., K. Nova. dan D. Septinova. 2014. Produksi Ternak Unggas.Anugrah Utama Raharja (AURA). Bandar Lampung

Muharlien. 2010. Meningkatkan kualitas telur melalui penambahan teh hijau dalam pakan ayam petelur. J. Ilmu dan 
Teknologi Hasil Ternak 5 (1) : 21 - 37.

Mountzouris, K. C., P. Tsitrsikos, I. Palamidi, A. Arvaniti, M. Mohnl, G. Schatzmayr and K. Fegeros. 2010. Effects of probiotic inclusion levels in broiler nutrition on growth performance, nutrient digestibility, plasma immunoglobulins, and cecal microflora composition. Poult Sci 89: 58-67.

Muchtadi, T. R. dan Sugiono. 1992. Ilmu Pengetahuan Bahan Pangan. Departemen Pendidikan dan Kebudayaan. Direktorat Jenderal Tinggi Pusat Antar Universitas Pangan dan Gizi. Institut Pertanian Bogor. Bogor.

Nugraha, B., K. Widayaka dan N. Iriyanti. 2013. Penggunaan berbagai jenis probiotik dalam ransum terhadap haugh unit dan volume telur ayam arab. J. Ilmiah Peternakan 1(2): 606-612.

Owings, W. J., D. L. Reynolds, R. J. Hasiak and R. Ferket. 1990. Influence of dietary supplementation with Streptococcus faecium M-74 on broiler body weight, feed conversion, carcass characteristics and intestinal microbial colonization. Poult. Sci. 69: 1257-1264.

Pribadia, A., T. Kurtinib dan Sumardic. 2015. Pengaruh pemberian probiotik dari mikroba lokal terhadap kualitas indeks albumen, indeks yolk, dan warna yolk pada umur telur 10 hari. J.Peternakan Terpadu. 3(3): 180-184.

Rahman, M. S. 2008. Effect of Acids on Laying Performance, Body Fatness and Egg Quality of Hens. Journal Animal of Science. 37 (2): 74 - 81.

Roberts, J. R. 2004. Factors Affecting Eggs Internal Quality in Laying Hens. Review. Journal Poultry of Science. 41: 161-177.

Sahara, E. 2010. Penggunaan Kepala Udang sebagai Sumber Pigmen dan Kitin dalam Pakan Ternak. Agrinak. 1 (1): 31-35.

Sarwono, B. 2002. Beternak Ayam Buras. Penebar Swadaya, Jakarta.

Stadellman, W. J. and O. J. Cotteril. 1995. Egg Science and Technology. Fourt Ed Food Product Press. An Imprint of the Haworth Press. Inc. New York. London.

Syamsir, E., S. Soekarto dan S. S. Mansjoer. 1994. Studi Komparatif Sifat Mutu dan Fungsional Telur Puyuh dan Telur Ayam Ras. Buletin Teknologi dan Industri Pangan. Bogor. 5 (3): 3-8.

Winarno, F. G. dan S. Koswara. 2002. Telur: Komposisi, Penanganan dan Pengolahannya, M-Brio Press, Bogor.

Willard, M. D., R. B. Simpson, N. D. Cohen and J. S. Clancy. 2000. Effects of dietary fructooligosaccharide onselected bacterial populations in feces of dogs. Am. J.Vet. Res. 61: 820-825.

Yamamoto, T., L. R. Juneja, H. Hatta and M. Kim. 2007. Hen eggs: basic and applied science. University of Alberta, Canada

Yesilbag, D. 2006. Effects of Organic Acid Supplemented Diets on Growth Performance, Egg Production and Quality and on Serum Parameters in Laying Hens. Review. Med. Vet. 157 (5): 280-284.

Youssev, A. W., H. M. A. Hassan, H. M. Ali and M. A. Mohamed. 2013. Effect of Probiotic, Prebiotik and Organic Acids on Layer Performance and Egg Quality. Journal of Poultry Science. 2013. 15 (2): 31-36.

Yuwanta, T. 2002. Telur dan Produksi Telur. Fakultas Peternakan. Universitas GadjahMada, Yogyakarta

Zainudin, D. 2006. Tanaman obat meningkatkan efisiensi pakan dan kesehatan ternak unggas. Balai Penelitian Ternak. Bogor. 